\title{
Rapid and sensitive PCR detection of Vibrio penaeicida, the putative etiological agent of Syndrome 93 in New Caledonia
}

\author{
Denis Saulnier*, Jean Christophe Avarre, Gilles Le Moullac, Dominique Ansquer, \\ Peva Levy, Vincent Vonau
}

Laboratoire d'Aquaculture Tropicale, Centre Océanologique du Pacifique, IFREMER, BP 7004, 98719 Taravao, Tahiti, French Polynesia

\begin{abstract}
Experimental infections of Penaeus (Litopenaeus) stylirostris were performed with a Vibrio penaeicida strain (AM101) isolated in New Caledonia from Syndrome 93 diseased shrimp. Cumulative mortalities resulting from intramuscular injection or immersion of shrimp in bacterial suspensions demonstrated high virulence for this bacterial strain and suggested that $V$. penaeicida could be the etiological agent of Syndrome 93. The median lethal dose ( $\mathrm{LD}_{50}$ ) for AM101 was $1.3 \times 10^{4} \mathrm{CFU}$ (colony forming units) $\mathrm{ml}^{-1}$ by immersion and less than 5 CFU shrimp ${ }^{-1}$ by intramuscular challenge, with mortality outbreaks at 48 and $22 \mathrm{~h}$ after challenge, respectively. A polymerase chain reaction (PCR) detection assay using a primer set designed from the $16 \mathrm{~S}$ ribosomal RNA gene of $V$ penaeicida was developed. It gave an expected amplicon of approximately $310 \mathrm{bp}$ in ethidium bromide-stained agarose gels The specificity of these primers was assessed with different Vibrio species. Furthermore, DNA extracted by the Chelex ${ }^{T M}$ method could be used to detect fewer than 20 cultured Vibrio cells in seawater or shrimp hemolymph by this assay. It appears to be a reliable screening method for detecting $V$. penaeicida in shrimp and from the aquatic environment.
\end{abstract}

KEY WORDS: Syndrome $93 \cdot$ Vibrio penaeicida PCR diagnosis - Shrimp disease - Vibriosis - Penaeus (Litopenaeus) stylirostris. Small subunit rDNA gene

\section{INTRODUCTION}

Vibriosis caused by Vibrio penaeicida is a disease that affects commercially reared shrimp Penaeus (Marsupenaeus) japonicus in Japan and results in great economic loss (Sano \& Fukada 1987, de la Peña et al. 1993, Takahashi et al. 1998). Since 1993, mortality outbreaks have been seasonally observed in semi-intensive Penaeus (Litopenaeus) stylirostris grow out ponds in New Caledonia, principally during winter when water temperatures rapidly drop (Mermoud et al. 1998). Epidemiological and bacteriological studies on this chronic or acute pathology, named 'Syndrome 93', revealed that moribund shrimp always suffered from severe bacterial septicemia mainly due to Vibrio species (Costa et al. 1998a, Mermoud et al. 1998). Using

•E-mail: dsaulnie@ifremer.fr conventional methods for bacterial identification, one group of Vibrio strains was found to predominate in moribund shrimp haemolymph. $V$. penaeicida was the main constituent of this group based on ribotypes and DNA percent reassociation in DNA/DNA hybridization assays (Costa et al. 1998a). Nevertheless, less than $70 \%$ DNA re-association was found between a $V$. penaeicida reference strain isolated from diseased P. japonicus in Japan (Ishimaru et al. 1995) and one isolated from diseased $P$. stylirostris in New Caledonia (Costa et al. 1998a). These strains also exhibited different ribotype profiles, depending on whether the bacterial isolates originated from New Caledonia or Japan. Differences were also observed by molecular typing using an arbitrarily primed polymerase chain reaction (PCR) technique (Goarant et al. 1999).

In this study, we evaluated the pathogenicity of Vibrio penaeicida strain AM101 and cloned and se- 
quenced a variable region of its $16 \mathrm{~S}$ rDNA. Sequence alignment confirmed that it belonged to $V$. penaeicida. Specific primers were designed for a diagnostic assay. We also demonstrated the reliability of the PCR technique as a tool for future epidemiological studies of $V$. penaeicida.

\section{MATERIALS AND METHODS}

Vibrio strains and cultivation methods. Four New Caledonian Vibrio strains and reference strains belonging to 17 Vibrio species were used (Table 1). Bacteria were stored at $-80^{\circ} \mathrm{C}$ and revived on nutrient medium containing $4 \mathrm{~g} \mathrm{l}^{-1}$ peptone, $1 \mathrm{~g} \mathrm{l}^{-1}$ yeast extract (Diagnostics Pasteur, Marnes la Coquette, France) and artificial seawater $2.3 \% \mathrm{wt} / \mathrm{vol} \mathrm{NaCl}, 20 \mathrm{mM} \mathrm{KCl}$, $5 \mathrm{mM} \mathrm{MgSO}_{4}, 2 \mathrm{mM} \mathrm{CaCl}_{2}$, until they reached the stationary phase by 15 to $20 \mathrm{~h}$ incubation at $27^{\circ} \mathrm{C}$ with agitation. The number of bacteria in culture suspensions was determined by spread plates of $100 \mu \mathrm{l}$ culture broth on nutrient agar (nutrient medium described above and supplemented with $1.5 \%$ agar). After a minimum of $16 \mathrm{~h}$ at $27^{\circ} \mathrm{C}$, bacterial colonies were counted and results expressed as the number of colony forming units (CFU) per ml of bacterial suspension.

Shrimp infection trials with strain AM101. All our experimental challenges with Vibrio isolates were conducted in a controlled area since $V$. penaeicida has not been reported from Tahiti. Shrimp used were healthy juveniles of Penaeus stylirostris belonging to the infectious hypodermal and haematopoietic necrosis virus (IHHNV) specific pathogen resistant strain (SPR43) reared in captivity at the Centre Océanologique du Pacifique (COP) for approximately 20 generations. They were acclimated to laboratory conditions in flowthrough tanks with no substrate bed for about $1 \mathrm{wk}$. Several batches, each consisting of 20 shrimp with weights ranging from 10 to $14 \mathrm{~g}$, were kept in $100 \mathrm{l}$ plastic tanks supplied with filtered and aerated water $(1 \mu \mathrm{m})$ at 24 to $26^{\circ} \mathrm{C}$. Juveniles were chosen because postlarval shrimp had been shown to be refractory to experimental infection with AM101 (Goarant et al. 1998).

Experimental infections were performed either by immersion of the shrimp for $2 \mathrm{~h}$ in $10 \mathrm{l}$ of seawater containing AM101, or by intramuscular injection between the fifth and sixth abdominal segments of $20 \mu \mathrm{l}$ of a bacterial suspension containing 250,2500 or $25000 \mathrm{CFU}$ $\mathrm{ml}^{-1}$ in artificial seawater prepared as indicated above. Control shrimp were similarly injected either with $20 \mu \mathrm{l}$ of this water or with $20 \mu \mathrm{l}$ of a suspension of Vibrio alginolyticus $\mathrm{Z} 1$ strain also isolated from Syndrome 93 diseased shrimp in New Caledonia. After $2 \mathrm{~h}$ immersion, the shrimp were rinsed carefully and abun-
Table 1. Strains examined by PCR and specificity of the PCR diagnosis assay using designed primers for Vibrio penaeicida. Except for $\mathrm{KH1} 1 \mathrm{1}^{\mathrm{T}}(=\mathrm{IFO} 15660 \mathrm{~T})$ isolated from Kuruma prawn in Kagoshima prefecture, Japan, strains of Vibrio penaeicida were isolated in New Caledonia from Syndrome 93 diseased Penaeus stylirostris. Vibrio alginolyticus, Z1 strain, was also isolated in New Caledonia from syndrome 93 diseased $P$. stylirostris. T' Type strain

\begin{tabular}{|c|c|c|}
\hline Vibrio species & $\begin{array}{l}\text { Source }^{a} \text { or } \\
\text { strain designations }\end{array}$ & $\begin{array}{l}\mathrm{PCR} \\
\text { reaction }^{b}\end{array}$ \\
\hline$V$. penaeicida & $\mathrm{KH}-1^{\top}\left(=\operatorname{IFO} 15660^{\top}\right)$ & + \\
\hline$V \cdot$ penaeicidac & AM101 & + \\
\hline$V \cdot p^{2} n a e i c i d a^{c}$ & AM23 & + \\
\hline$V \cdot$ penaeicida & $\mathrm{F} 2$ & + \\
\hline$V \cdot p^{2} n a e i c i d a^{c}$ & SF 143 & + \\
\hline V.alginolyticus & $\mathrm{Z1}$ & - \\
\hline \multicolumn{3}{|l|}{$V$. spp. } \\
\hline (V. nigripulchritudo?) & AM100 & - \\
\hline V. alginolyticus & $\operatorname{ATCC} 17.749^{\mathrm{T}}$ & - \\
\hline V. campbelli & CIP 7.057 & - \\
\hline V. carchariae & LMG 7.890 & - \\
\hline$V$ damsela & $\operatorname{CIP} 102.761^{\mathrm{T}}$ & - \\
\hline$V$. fluvialis & CIP $103.355^{\top}$ & - \\
\hline V. gazogenes & VIB $294^{\top}$ & - \\
\hline V. harveyi & LMG 4.044 & - \\
\hline V. hollisae & CIP $101.886^{\mathrm{T}}$ & - \\
\hline V. navarensis & $\operatorname{CIP} 103.381^{\mathrm{T}}$ & - \\
\hline$V$. nereis & LMG $3.895^{\mathrm{T}}$ & - \\
\hline V. nigripulchritudo & CIP 103.195 & - \\
\hline$V$ orientalis & LMG 7.897 & - \\
\hline$V$ proteolyticus & CIP 102.892 & - \\
\hline V. splendidus & CIP $102.893^{\mathrm{T}}$ & - \\
\hline V. tubiashii & CIP $102.760^{\mathrm{T}}$ & - \\
\hline \multicolumn{3}{|l|}{ V. harveyil } \\
\hline V. parahaemolyticus? & $98-156 / 7^{d}$ & - \\
\hline V.parahaemolyticus & $69 / \mathrm{B}^{\mathrm{d}}$ & - \\
\hline \multicolumn{3}{|c|}{$\begin{array}{l}\text { 'ATCC, American Type Culture Collection, Rockville, } \\
\text { MD; CIP, Collection de l'Institut Pasteur, Paris, France; } \\
\text { IFO, Institute for Fermentation Osaka, Japan, LNG, Bel- } \\
\text { gian Coordinated Collection of Microorganisms, Labora- } \\
\text { tory voor Microbiologie, Universiteit, Gent }\end{array}$} \\
\hline \multicolumn{3}{|c|}{$\begin{array}{l}\mathrm{b}+\text {, only } 1 \text { amplification product of } 311 \mathrm{bp}_{i-} \text {, no amplifica- } \\
\text { tion products }\end{array}$} \\
\hline \multicolumn{3}{|c|}{$\begin{array}{l}\text { "Strains determined to belong to } V \text {. penaeicida on the } \\
\text { basis of the results of DNA re-association obtained in } \\
\text { DNA/DNA hybridization assays using labeled AM23 } \\
\text { strain (Costa et al. 1998) }\end{array}$} \\
\hline \multicolumn{3}{|c|}{$\begin{array}{l}\text { dSupplied by Dr Monhey and isolated from diseased } \\
\text { shrimp in Madagascar }(98-156 / 7) \text { and Ecuador }(9069 / \mathrm{B} 3)\end{array}$} \\
\hline
\end{tabular}

dantly with filtered seawater and then transferred to tanks (100 l of aerated water). Mortalities were recorded over the following $7 \mathrm{~d}$.

DNA extraction. Except for primer specificity assays where DNA was extracted using a standard SDS, Proteinase $\mathrm{K}$ digestion followed by chloroform, phenol extraction (Jackson et al. 1991), genomic DNA was extracted with Chelex ${ }^{\mathrm{T}} 100$ (Sigma, St. Louis, MO, USA). Briefly, each haemolymph or seawater sample 
was centrifuged at $10000 \times g$ for $10 \mathrm{~min}$, and the supernatant fluid was removed. The pellet was resuspended in $400 \mu \mathrm{l}$ of a $5 \%$ (wt/vol) Chelex ${ }^{\mathrm{rM}} 100$ solution (prepared in $10 \mathrm{mM}$ Tris buffer, $\mathrm{pH} 8.0$, using deionized water). Then $50 \mu \mathrm{l}$ of Proteinase $\mathrm{K}$ (at a final concentration of $25 \mu \mathrm{g} \mathrm{ml}^{-1}$, Merck, Darmstadt, Germany) was added, and samples were incubated for 4 h at $56^{\circ} \mathrm{C}$, boiled at $100^{\circ} \mathrm{C}$ for $10 \mathrm{~min}$, and immediately put on ice The supernatant was used directly as template material for PCR, without prior centrifugation and taking care not to pipet the Chelex ${ }^{\mathrm{TM}}$ beads.

Cloning and sequencing of a PCR product from Vibrio penaeicida AM101 strain 16S rRNA gene. A sense primer, 5'-ccgaattcGGAATATTGCACAATGGGCGC-3' (VecoF) and an antisense primer, 5'-ggatcctcgagGCGCTTTACGCCCAGTAATTCCG-3' (VxhoR) were designed and synthesized (Eurogentec, Seraing, Belgium) in accordance with the procedures for partial 16S rRNA sequence alignments (Kita-Tsukamoto et al. 1993, Genmoto et al. 1996). These primers were flanked at their respective $5^{\prime}$ ends with EcoRI and Xhol cloning restriction sites (shown in the primer sequence as small characters). Their 3'-terminal nucleotide sequences corresponded to 2 highly conserved regions of the $16 \mathrm{~S}$ rRNA gene among the members of the family Vibrionaceae, including the genus Vibrio. VecoF and VxhoR primers are located at bases 346 to 366 (Fig. 1) and at bases 541 to 563 in the 16S rRNA gene (GenBank accession number Z83204), respectively, according to the Escherichia coli numbering system (Brosius et al. 1981).

PCR amplification was carried out in a $50 \mu$ reaction mixture containing the extracted DNA (25 $\mu l)$, the reaction buffer $(10 \mathrm{mM}$ Tris-HCl, $\mathrm{pH} 9.0,50 \mathrm{mM}$ $\mathrm{KCl}, 2.5 \mathrm{mM} \mathrm{MgCl}_{2}, 0.1 \%$ Triton X100), $200 \mu \mathrm{M}$ of each dNTP (Eurogentec), $0.2 \mu \mathrm{M}$ of each primer and $0.2 \mathrm{U}$ of GoldStar ${ }^{\mathrm{TM}}$ DNA polymerase (Eurogentec) in an automatic thermal cycler (MJ Research). The thermal profile involved 35 cycles of denaturation at $94^{\circ} \mathrm{C}$ for $1 \mathrm{~min}$, annealing at $58^{\circ} \mathrm{C}$ for 1 min and elongation at $72^{\circ} \mathrm{C}$ for $1 \mathrm{~min}$, followed by final extension at $72^{\circ} \mathrm{C}$ for $5 \mathrm{~min}$ and holding at $4^{\circ} \mathrm{C}$. The resulting PCR product was purified from an agarose electrophoresis gel using a Qiaex ${ }^{\circledR}$ kit (Qiagen, Courtaboeuf, France) and ligated into a EcoRI/ XhoI-cleaved pBluescript plasmid con- taining a gene for ampicillin resistance. Competent Escherichia coli (DH5o) cells were transformed and successful transformants growing on nutrient agar medium supplemented with ampicillin were then screened by restriction endonuclease analysis. Clones containing rDNA inserts were sequenced and analysed. The determined amplicon sequence was deposited in the GenBank data base under accession number AJ249719

PCR for diagnostic assays. A sense primer 5'-GTGTGAAGTTAATAGCTTCATATC-3' (VpF) was selected from a highly variable region of the $16 \mathrm{~S}$ rRNA gene (Kita-Tsukamoto et al. 1993) after alignment of the AM101 rDNA sequence with other known rDNA sequences from Vibrio species at GenBank. By contrast, the reverse primer 5'-CGCATCTGAGTGTCAGTATCT-3' (VR) was chosen from a conserved region of the $16 \mathrm{~S}$ rRNA gene found in 17 Vibrio species (Kita-

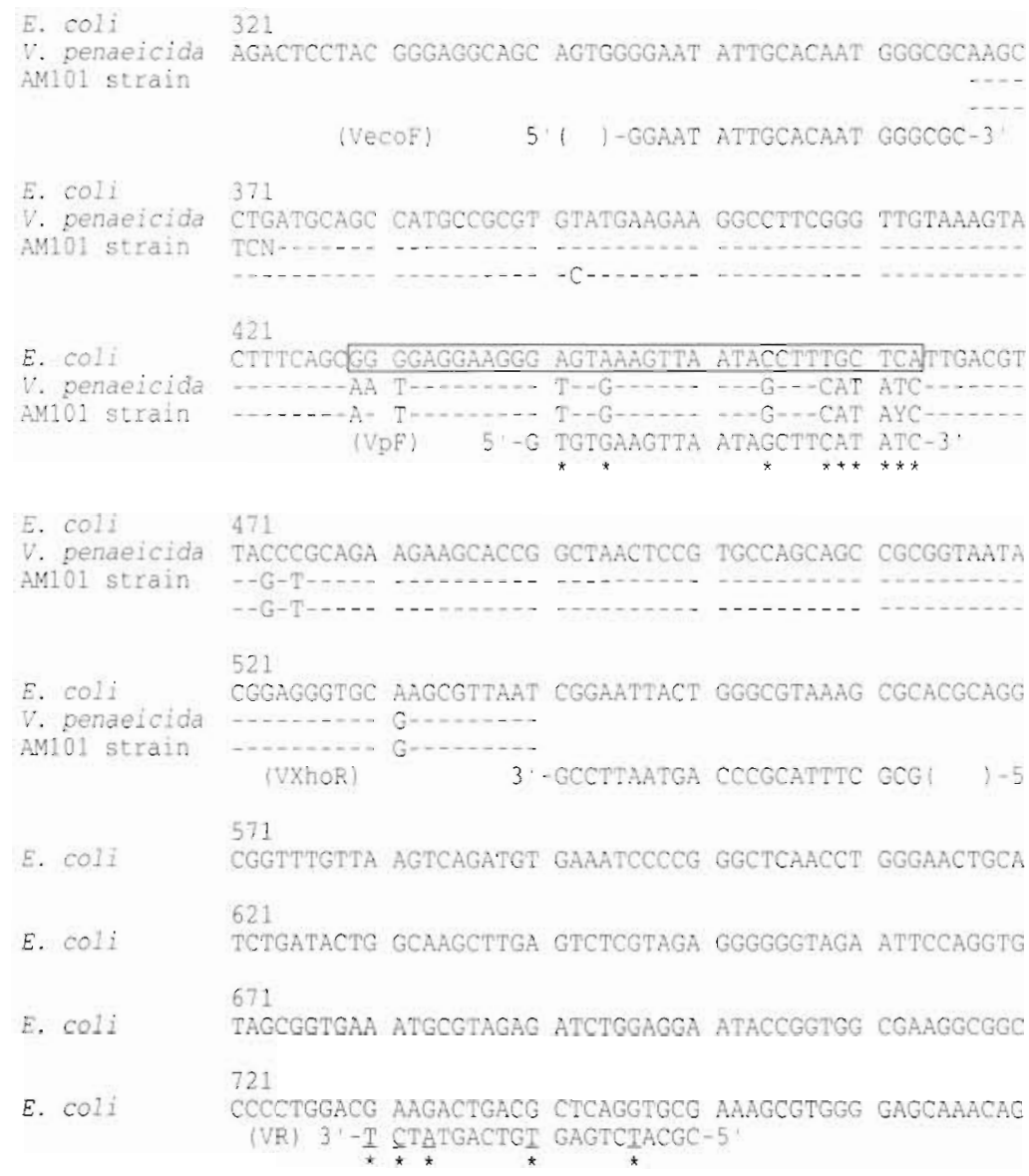

Fig. 1. Partial 16S rRNA sequences of Escherichia coli sequence aligned with Vibro penaeicida (Genmoto et al. 1996) and cloned $V$. penaeicida strain AM101. Primers for PCR are localised according to E. coli numbering. Variable regions of $16 \mathrm{~S}$ rRDNA of Vibrionaceae and specific nucleotides for main groups of Vibrio species (Kita-Tsukamoto et al. 1993) are indicated by a box and underlining, respectively. *: non-complementary bases between the primers and the $E$. coli sequences. Nucleotides: $N=A, C, G$, or $T ; Y=$ pyrimidine $(\mathrm{C}$ or $\mathrm{T})$ 
Tsukamoto et al. 1993). VpF and VR primers were synthesized by Eurogentec. They were located at bases 440 to 463 and at bases 730 to 750 , respectively, in the 16S rRNA gene sequence (GenBank accession number Z83204) from Escherichia coli (Fig. 1). PCR reaction mixtures were identical to those described above, except that the reaction was performed with $0.1 \mathrm{U}$ of Goldstar ${ }^{\mathrm{TM}}$ DNA polymerase and $10 \mathrm{\mu l}$ of Chelex $\mathrm{TM}_{-}$ extracted DNA, in a final volume of $20 \mu \mathrm{l}$. The PCR conditions used were $1 \mathrm{~min}$ at $94^{\circ} \mathrm{C}$ for initial denaturation of template DNA and 35 cycles each consisting of $30 \mathrm{~s}$ at $94^{\circ} \mathrm{C}$ (denaturation), $30 \mathrm{~s}$ at the selected annealing temperature, $30 \mathrm{~s}$ at $72^{\circ} \mathrm{C}$ (extension), followed by a final round of extension for $5 \mathrm{~min}$ at $72^{\circ} \mathrm{C}$ using the same automated DNA thermal cycler as mentioned before.

Positive controls used for each PCR assay consisted of AM101 DNA extract while negative controls consisted of deionized water. Amplification products were run at a constant voltage of $5 \mathrm{~V} \mathrm{~cm}^{-1}$ on 1 to $2 \%$ (wt/vol) agarose gels with TBE electrophoresis buffer ( $45 \mathrm{mM}$ Tris, $45 \mathrm{mM}$ Borate, $1 \mathrm{mM}$ EDTA). They were stained with $0.5 \mu \mathrm{g} \mathrm{ml}^{-1}$ ethidium bromide and visualized by UV transillumination.

Sensitivity assays. Haemolymph from 20 healthy Penaeus stylirostris was withdrawn from the ventral sinus with a $1 \mathrm{ml}$ sterile syringe containing an equal volume of anticoagulant solution (trisodium citrate $30 \mathrm{mM}, \mathrm{NaCl} 338 \mathrm{mM}$, glucose $115 \mathrm{mM}$, EDTA $10 \mathrm{mM}$, $\mathrm{pH} 7$ ) and pooled. An AM101 culture of known cell concentration in Zobell medium was serially diluted 10 fold in $0.5 \mathrm{ml}$ aliquots of both haemolymph and seawater, and the CFU ml ${ }^{-1}$ of each sample was verified by the plate count method. Ten or $200 \mu \mathrm{l}$ of these samples were then taken for DNA extraction. Prior to DNA extraction, the $200 \mu \mathrm{l}$ samples were centrifuged at 10000 $\times g$ for $10 \mathrm{~min}$, the supernatant poured of $\mathrm{and}$ the pellet resuspended in $450 \mu$ l of Chelex ${ }^{\mathrm{TM}}$-Proteinase $\mathrm{K}$ solution as already described. The $10 \mu \mathrm{l}$ samples were extracted directly with $450 \mu$ l of Chelex ${ }^{\mathrm{TM}}$-Proteinase $\mathrm{K}$ solution (i.e. without prior centrifugation).

\section{RESULTS}

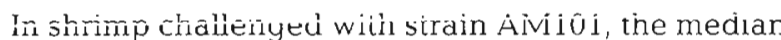
lethal dose $\left(\mathrm{LD}_{50}\right)$ was $1.3 \times 10^{4} \mathrm{CFU} \mathrm{ml^{-1 }}$ by immersion and less than 5 CFU shrimp ${ }^{-1}$ by intramuscular injection, with mortality onset after challenge at 48 and $22 \mathrm{~h}$ (Fig. 2b), respectively. No significant mortalities were observed in controls injected with artificial seawater or Vibrio alginolyticus Z1. In addition, pure cultures of bacteria were obtained from 20 diseased shrimp, in most cases from the haemolymph spread on agar plates. In other cases, the dominant bacteria were con-
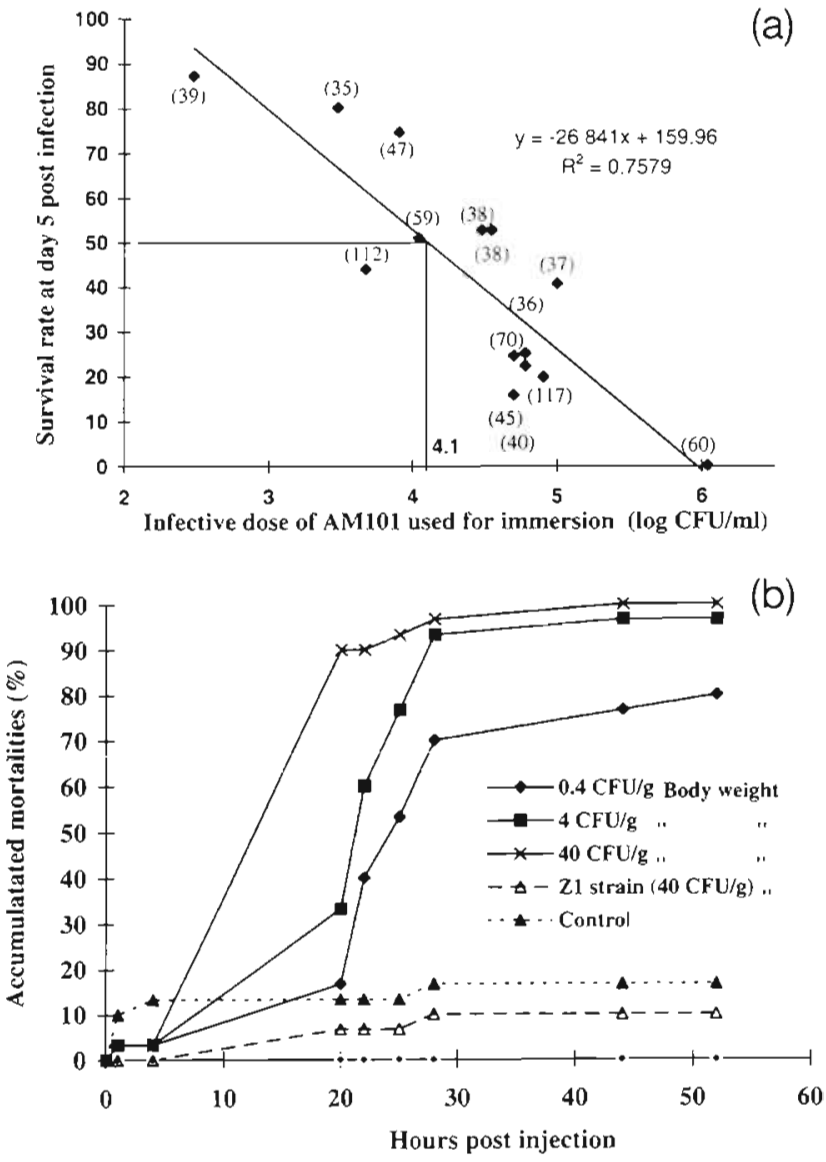

Fig. 2. Mortality data from pathogenicity experiments with AM101 strain. (a) Cumulative mortalities (in \%) obtained at Day 5 following $2 \mathrm{~h}$ immersion in seawater containing the final concentrations of bacteria indicated. Data were compiled from a series of thirteen. $2 \mathrm{~h}$ immersion challenges. The number of Penaeus stylirostris taken for each challenge is given in brackets. (b) Cumulative mortalities obtained at various hours after intramuscular injection of bacterial suspensions. Each treatment comprised 30 shrimp

firmed as $V$. penaeicida by the PCR assay described herein. PCR identified bacterial isolates from these shrimp succeeded in reproducing morbidities and mortalities by intramuscular injection or immersion challenges, and thus Koch's postulates were fulfilled. In contrast to immersion challenge, there was no relationship between dose and level of mortality using intramuscular injection. More than $50 \%$ cumulative mortality was observed within $2 \mathrm{~d}$ even with a very low number of injected bacteria, indicating high virulence (Fig. 2). However, results did show some delay in mortality onset when low numbers of bacterial cells were injected. This could correspond to a dosedependent swiftness in spread of septicemia. Onset of mortality was between 4 and $20 \mathrm{~h}$ post-injection using $40 \mathrm{CFU} \mathrm{g}^{-1}$ and between 20 and $22 \mathrm{~h}$ using $0.4 \mathrm{CFU} \mathrm{g}^{-1}$. 


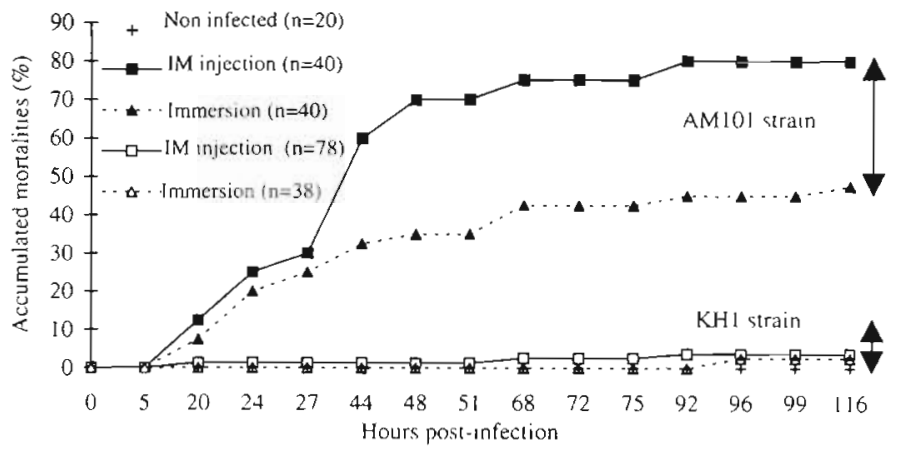

Fig. 3. Virulence of AM101 and KH1 strains in experimental infections. Penaeus stylirostris weighing approximately $8 \mathrm{~g}$ were infected with $\mathrm{AM} 101$ or $\mathrm{KH} 1$ strains either by $2 \mathrm{~h}$ immersion chal-

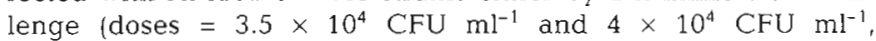
respectively) or by intramuscular (IM) injection (dose $=3 \mathrm{CFU} \mathrm{g}^{-1}$ body weight and 5 CFU g ${ }^{-1}$ body weight, respectively). The number of shrimp for each challenge is given in brackets

Most experimentally infected shrimp exhibited gross signs of classical bacteremia (Lightner \& Lewis 1975). Haemolymph samples collected from 30 eye-stalk tagged shrimp infected by immersion showed positive results by PCR $16 \mathrm{~h}$ post exposure, before the appearance of gross signs of disease and death. Thus, asymptomatic carriers could be detected by this technique. It is noteworthy that the Japanese type strain $\mathrm{KH}-1^{\top}$ iso- lated from Penaeus japonicus did not exhibit any noticeable pathogenic effects on $P$. stylirostris (gross signs or mortalities), whatever the route of infection (Fig. 3). This constrasted with Vibrio penaeicida isolates from New Caledonia and particularly strain AM101.

Amplification of AM101 DNA extract with VecoR and VxhoR primers resulted in an expected $230 \mathrm{bp}$ single PCR product (Fig. 1). The nucleotide sequence of this $16 \mathrm{~S}$ rRNA gene fragment was found to be very close, but not identical to that for Vibrio penaeicida (Genmoto et al. 1996) by sequence alignment, particularly in the highly variable region (440 to $463 \mathrm{bp}$, Fig. 1). This provided additional evidence that AM101 isolated in New Caledonia belonged to $V$. penaeicida.

To develop an optimal diagnostic assay, 2 additional primers (VpF) and (VR) (see 'Materials and methods') were tested (Fig. 1). PCR amplification with these primers at a $62^{\circ} \mathrm{C}$ annealing temperature yielded a single, $310 \mathrm{bp}$ DNA fragment (expected length). Under these conditions, it was the only product obtained with DNA extracted from Vibrio penaejcida strains originating from either New Caledonia or Japan (Table 1). No amplification products were observed with the other Vibrio species shown in Table 1. (a)

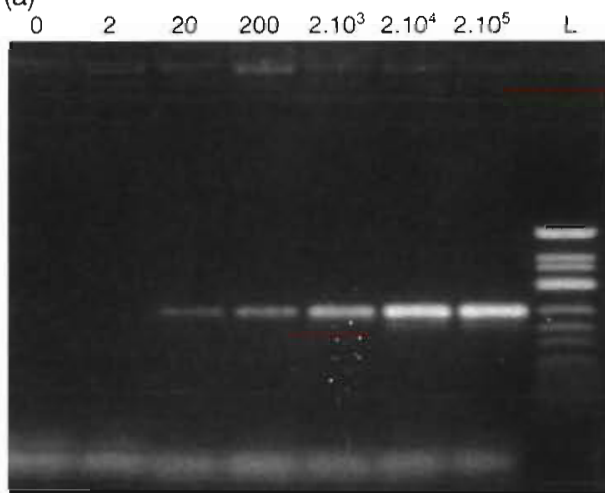

Fig. 4. Agarose gel ( $1 \%$ ) elec trophoretic analysis of PCRamplified products obtained using $\mathrm{VpF}$ and $\mathrm{VR}$ primers with various concentrations of pure AM101 (a) diluted in seawater or (b) in hemolymph from healthy $P e$ naeus stylirostris. Bacterial DNA was Chelex ${ }^{\text {TM-ex- }}$ tracted either (c,d) without sample centrifugation for $10 \mu$ samples or $(a, b)$ after centrifugation at $10000 \times \mathrm{g}$ for $200 \mu l$ samples. Lanes: $\mathrm{L}$, ladder size markers from \$X174 plasmid digested with Hinfl enzyme (Eurogentec)

(c)

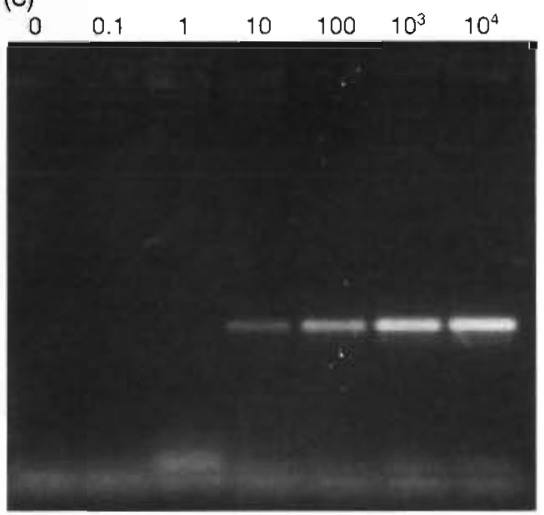

(b)

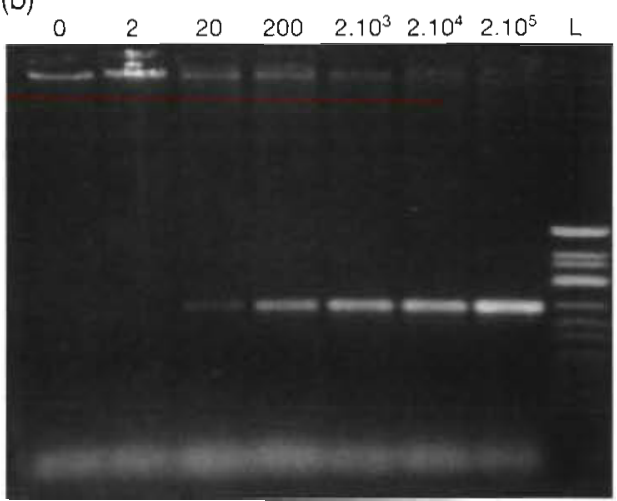

(d)

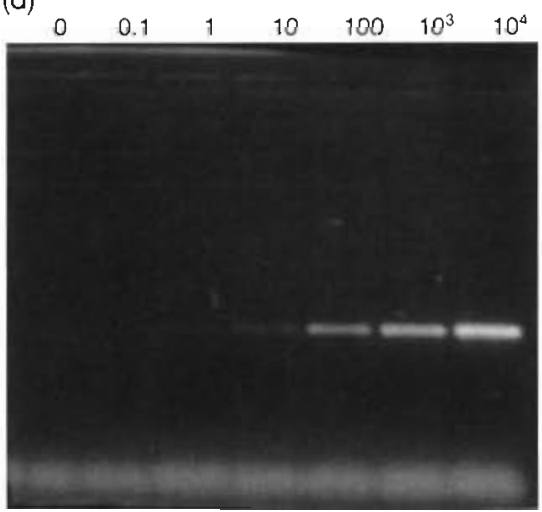


In PCR sensitivity tests using serial 10-fold dilutions of AM101 either in seawater or in haemolymph, the detection limit was about 20 Vibrio penaeicida genome equivalents as determined by the plate count method (Fig. 4). It is important to note that large haemolymph samples must be centrifuged before DNA extraction. Without centrifugation, no more than $10 \mu \mathrm{l}$ of haemolymph could be efficiently amplified by PCR using the Chelex ${ }^{T M}$ method. This suggested the presence of some PCR inhibitory compounds in haemolymph. Thus, we recommenc that approximately $200 \mu$ be centrifuged to remove plasma and to increase sensitivity of the PCR method. In this way positive results were obtained with dilutions corresponding to $100 \mathrm{~V}$. penaeicida CFU per ml of haemolymph (Fig. 4).

\section{DISCUSSION}

Experimental shrimp infection by immersion using AM101 allowed reproducible tests with a high correlation between dose and mortality. This constitutes an interesting model for studying the shrimp response to non-invasive infection. Reproducibility was successfully obtained using careful storage of AM101 strain at $-80^{\circ} \mathrm{C}$, standardized growing techniques in appropriate media and standardized infection schedules in a controlled environment.

The percentage of DNA/DNA reassociation between the New Caledonian isolate (AM23 strain) and the Japanese Vibrio penaeicida reference strain (KH1 strain) was found to be approximately $60 \%$ (Costa et al. 1998a). Based on the phylogenetic definition of species by Wayne et al. (1987), this would disqualify the 2 strains from being considered the same species. Nevertheless, the level of sequence identity in the variable region of the SSU IRNA gene between the New Caledonian AM101 and the $V$. penaeicida reference strain isolated from Japan indicates that AM101 strain does belong to $V$. penaeicida. Based on the PCR results, other highly pathogenic bacterial isolates from New Caledonia also belong to $V$. penaeicida (Table 1)

The high virulence of the bacterial strains isolated in New Caledonia from Syndrome 93 diseased Penaeus stylirostris was demonstrated by experimental infectiüins using 2 different routes of infection and water temperatures not stressful for shrimp. By intramuscular injection, the virulence of New Caledonian Vibrio penaeicida isolates on $P$. stylirostris was found to be higher than the Japanese $V$. penaeicida isolates tested by de la Peña et al. (1993) with P. japonicus. Our LD L $_{50}$ values were lower than 5 CFU shrimp ${ }^{-1}$ (10 to $14 \mathrm{~g}$ ) while those of de la Peña et al. (1993) were $1 \times 10^{2}$ to $10^{3}$ CFU shrimp ${ }^{-1}$ (13 to $22 \mathrm{~g}$ ). These results strongly suggest that $V$. penaeicida is a specific rather than opportunistic agent in contrast to many other Vibrio species which produce disease only in stressed shrimp (Lightner 1988). Based on our results, we consider this highly pathogenic $V$. penaeicida strain as the main etiological agent of Syndrome 93, especially since studies on viral etiology have shown little success to date (Costa et al. 1998b).

Several reports have pointed out the low reproducibility and instability of some phenotypic markers commonly used for bacterial identification because of their sensitivity to experimental culture conditions (Hovik Hansen \& Sorheim 1991). Furthermore, marker variability is sometimes insufficient to allow differentiation between related bacteria species, and characterization systems for marine bacteria identification are often laborious and time consuming. Therefore, diagnostic identification based on DNA fragment detection is an important alternative to classical phenotypical studies. In our study, this method was rapid, highly sensitive, specific and able to detect viable, but not necessarily culturable bacteria (Morgan et al. 1993). These techniques have been extensively developed for a wide range of pathogenic bacteria, especially those considered to be human health hazards (Wright et al. 1993, Leon et al. 1994, Martinez-Picado et al. 1994, Toyama et al. 1994, Arias et al. 1995, Miyata et al. 1996, Venkateswaran et al. 1998).

Recently, Genmoto et al. (1996) described a diagnostic procedure for the identification of Vibrio penaeicida in bacterial cultures isolated from diseased Penaeus japonicus. They recommended a reverse transcriptase step before amplification of the partial SSU rDNA sequence of $V$. penaeicida by PCR, in order to increase the sensitivity of the assay. Our results, using the same sense but different antisense primer, indicate that approximately 20 bacterial genome equivalents in seawater or haemolymph samples are sufficient for visual detection of the expected PCR product in agarose gels. Furthermore, specificity of the test was demonstrated using DNA extracts from pure reference cultures of other Vibrio species which did not cross-react. The diagnostic test is easy to perform on very large numbers of samples since DNA is much more stable than RNA, and the procedure for DNA extraction by Chelex ${ }^{\mathrm{TM}}$ is very fast. Moreover, this Chelex ${ }^{\mathrm{rM}}$ method enables DNA extractions directly in the field, and only requires previous preparation of the extraction mixture. If centrifugation cannot be performed in the field, an alternative DNA extraction with smaller amounts of haemolymph or seawater is possible, although this would decrease the sensitivity of the test by a factor of 20

In conclusion, a sensitive, specific and reliable diagnostic method has been established for detection of Vibrio penaeicida both in seawater and in haemolymph of infected shrimp. This method could be of great value 
for monitoring the presence of this agent in the marine environment and for correlating environmental factors affecting spatial and temporal distributions of the infectious disease it causes. Finally, rapid identification of $V$. penaeicida (within $12 \mathrm{~h}$ after sampling) allows time for intervention to prevent the spread of infections.

Acknowledgements. We thank Esther Lubzens for critically reading the manuscript. We are also grateful to Dr Franck Berthe for supplying the bacterial reference strains used in Table 1

\section{LITERATURE CITED}

Arias CR, Garay E, Aznar R (1995) Nested PCR method for rapid and sensitive detection of Vibrio vulnificus in fish, sediments and water. Appl Environ Microbiol 61(9): $3476-3478$

Brosius J, Dull TJ, Sleeter DD, Noller HF (1981) Gene organization and primary structure of a ribosomal RNA operon from Escherichia coli. J Mol Biol 148(2):107-127

Costa R, Mermoud I, Koblavi S, Morlet B, Haffner P, Berthe F Legroumellec M, Grimont P (1998a) Isolation and characterization of bacteria associated with a Penaeus stylirostris disease (Syndrome 93) in New Caledonia. Aquaculture $164: 297-309$

Costa R, Mermoud I, Mari J, Bonami JR, Hasson K, Lightner DV (1998b) Investigations of Penaeus stylirostris disease (Syndrome 93) in New Caledonia, exploring a viral hypothesis. Aquaculture 164:311-322

de la Peña LD, Tamaki T, Momoyama K, Nakai T, Muroga K (1993) Characteristics of the causative bacterium of vibriosis in the Kuruma prawn, Penaeus japonicus. Aquaculture 115:1-12

Genmoto K, Nishizawa T, Nakai T, Muroga K (1996) $16 \mathrm{~S}$ rRNA targeted RT-PCR for the detection of Vibrio penaeicida, the pathogen of cultured kuruma prawn Penaeus japonicus. Dis Aquat Org 24:185-189

Goarant C, Régnier F, Brizard R, Marteau AL (1998) Acquisition of susceptibility to Vibrio penaeicida in Penaeus stylirostris postlarvae and juveniles. Aquaculture 169: $291-296$

Goarant C. Mérien F, Berthe F, Mermoud I, Pérolat P (1999) Arbitrarily primed PCR to type Vibrio spp. pathogenic for shrimp. Appl Environ Microbiol 65(3):1145-1151

Hovik Hansen G, Sorheim R (1991) Improved method for phenotypical characterization of marine bacteria. J Microbiol Methods 13:231-241

Ishimaru K, Akagawa-Matsushita M, Muroga K (1995) Vibrio penaeicida sp. nov., a pathogen of Kuruma prawns (Penaeus japonicus). Int J Syst Bacteriol 45:134-138

Jackson DP, Hayden JD, Quirke P (1991) Extraction of nucleic acid from fresh and archival material. In: McPherson $\mathrm{MJ}$,

Editorial responsibility: Timothy Flegel,

Bangkok, Thailand
Quirke P, Taylor GR (eds) PCR: a practical approach. IRL Press at Oxford University Press, Oxford, p 29-49

Kita-Tsukamoto K, Oyaizu H, Nanba K, Simudu U (1993) Phylogenetic relationships of marine bacteria, mainly members of the family Vibrionaceae, determined on the basis of 165 rRNA sequences. Int J Syst Bacteriol 43:8-19

Leon G, Maulen N, Figueroa J, Villanueva, Rodriguez C, Vera MI, Krauskopf MA (1994) A PCR-based assay for the identification of the fish pathogen Renibacterium salmoninarum. FEMS Microbiol Lett 115:131-136

Lightner DV (1988) Diseases of cultured and penaeid shrimp and prawns. In: Sindermann CJ, Lightner DV (eds) Disease diagnosis and control in North American marine aquaculture. Elsevier, Amsterdam, p 8-127

Lightner DV (1992) Shrimp pathology: major diseases of concern to the farming industry in the Americas. In: Calderón J, Sandoral V (eds) Memorias del primer congreso ecuatoriano de acuicultura. CENAIM, Guayaquil, p 117-195

Lightner DV, Lewis DH (1975) A septic bacterial disease syndrome of penaeid shrimp. Mar Fish Rev 37:25-28

Martinez-Picado J, Alsina $M$, Blanch AR, Cerda $M$, Joffre J (1996) Species specific detection of Vibrio anguillarum in marine aquaculture environments by selective culture and DNA hybridization. Appl Environ Microbiol 62(2):443-449

Mermoud I, Costa R, Ferré O, Goarant C, Haffner P (1998) 'Syndrome 93' in New Caledonia outdoor rearing ponds of Penaeus stylirostris: history and description of three major outbreaks. Aquaculture 164:323-335

Miyata M, Inglis V, Aoki $T$ (1996) Rapid identification of Aeromonas salmonicida subsepecies salmonicida by PCR. Aquaculture 141:13-24

Morgan JAW, Rhodes G, Pickup RW (1993) Survival of nonculturable Aeromonas salmonicida in lake water. Appl Environ Microbiol 59(3):874-880

Sano $T$, Fukuda $H$ (1987) Principal microbial diseases of mariculture in Japan. Aquaculture 67:59-69

Takahashi Y, Itami T, Maeda M, Kondo M (1998) Bacterial and viral diseases of Kuruma shrimp (Penaeus japonicus). Japan. Fish Pathol 33(4):357-364

Toyama T, Kita-Tsukamoto K, Wakabayashi H (1994) Identification of Cytophaga psychrophila by PCR targeted $16 \mathrm{~S}$ ribosomal RNA. Fish Pathol 29:271-275

Venkateswaran K, Dohmoto N. Harayama S (1998) Cloning and nucleotide sequence of the gyr $\mathrm{B}$ gene of Vibrio parahaemolyticus and its application in detection of this pathogen in shrimp. Appl Environ Microbiol 64(2): $681-687$

Wayne LG, Brenner DJ, Colwell RR, Grimont PAD, Kandler O, Krichevsky, Moore LH, Moore WEC, Murray RGE, Stackebrandt E, Starr MP, Trüper HG (1987) Report of the ad hoc commitee on reconciliation of approaches to bacterial systemics. Int J Syst Bacteriol 37(4):463-464

Wright AC, Miceli GA, Landry WL, Christy JB, Watkins WD, Morris JG (1993) Rapid identification of Vibrio vulnificus on non selective media with an alkaline phosphatase labeled oligonucleotide probe. Appl Environ Microbiol 59(2):541-546

Submitted: June 9, 1999; Accepted: November 10, 1999 Proofs received from author(s): February 16, 2000 